\title{
A Quarter-Century Focus on Improving Service Quality
}

Cornell Hospitality Quarterly

2014, Vol. 55(3) 220

(c) The Author(s) 2014

Reprints and permissions:

sagepub.com/journalsPermissions.nav DOI: $10.1177 / 1938965514538587$

cqx.sagepub.com
The first International Quality in Service Symposium (QUIS) that took place in 1988 in Karlstad, Sweden, represented a particularly important starting point and stimulus for the scientific discussion of service management issues. Since then, service management research has developed significantly, and a specific scientific community has evolved. At several prestigious universities all over the world, service research centers have been established and a growing number of service-related books have been published. Moreover, an increasing number of academic journals with a focus on services are gaining an international reputation.

Within this impressive development of service research, the biennial QUIS conference remains one of the most important driving forces. QUIS is a place where researchers present latest empirical insights and share their ideas. It is a forum for an intensive international dialogue not only between academics but also between researchers and executives. QUIS13 (the 13th International Research Symposium on Service Excellence in Management) hosted by Service Research Center, Karlstad University, Sweden, on June 10-13, 2013, attracted approximately three hundred leading researchers and industry executives from more than thirty countries around the world.

This special issue represents selected papers from the QUIS13 conference that received highest level of feedback during a multi-stage review process. First, over two hundred submitted papers were reviewed by four conference co-chairs (Mary Jo Bitner, Bo Edvardsson, Anders Gustafsson, and myself). Second, the session chairs provided a rating of papers presented during the conference. Third, on the basis of earlier reviews, the authors of twenty articles were invited to submit papers for consideration for publication in this special issue. Fourth, each submitted article was further reviewed by one or two additional reviewers. Finally, the accepted papers are included within this special issue.

I would like to thank Quarterly Editor Michael LaTour for giving me the opportunity to edit this special issue that represents some of the best research presented during the QUIS13 conference. I would also like to thank Glenn Withiam for his detailed review and editing of the accepted manuscripts. Finally, I would like to sincerely thank my conference co-chairs and several members of the conference planning committee who wholeheartedly assisted me through various stages of planning and execution of the QUIS13 conference and this special issue.

$$
\begin{array}{r}
\text { Sincerely } \\
\text { Rohit Verma } \\
\text { QUIS13 Co-Chair } \\
\text { Singapore Tourism Board Distinguished Professor } \\
\text { Professor of Service Operations Management } \\
\text { School of Hotel Administration } \\
\text { Cornell University } \\
\text { rv54@cornell.edu }
\end{array}
$$

\section{Note from the Editor}

Thank you, Professor Verma.

Once again, Professor Rohit Verma provides Cornell Hospitality Quarterly $(C Q)$ with a very high-quality collection of papers from the most recent QUIS conference. The vetting process was very rigorous and the resulting works are both insightful as well as key for future studies to build upon. I know the readers of $C Q$ will find tremendous value in this issue. Again, my most sincere thanks to Professor Verma and his team of reviewers.

$-M . S . L$ 